\title{
Subjects in Difference: Walter Benjamin, Frantz Fanon, and Postcolonial Theory
}

As commonplace as it is to note that the failure of postcolonial regimes and the continuation of imperialist wars has lead postcolonial scholarship to ring its insights in a melancholic key, such melancholia has perhaps irrevocably highlighted the difference between the given state of the world and the uncertain concepts with which we seek to apprehend it. It has, in other words, forced a greater attention to the sufficiency of our own reading practices. Some of the finer examples of this focus on reading practice itself are Dipesh Chakrabarty's attempts to rethink historical difference, David Scott's call to deploy tragedy rather than romance as the most fitting narrative for nationalist liberation movements, and even Gayatri Chakravorty Spivak's cautionary tale about imputing a voice to subaltern figures ("Can the Subaltern Speak?"). As each of these examples makes clear, to focus on reading practice means, simultaneously, to attend to the object at hand and by means of a reorientation of vision, refunction the object itself.

Such a reorientation of vision may take the form of excavating an archive for newly constituted objects of postcolonial study, rethinking 
the foundational categories of political representation as a concomitant process of such archiving, and producing new forms of reading that place unexpected elements into play with each other. The work of the Subaltern Studies Collective encompassed each of these reorientations. At stake at each reorientation is a revision of the relationship between the object and the concept, on the one hand, and inherited tradition and its interruption, on the other. The political and cultural implications of subaltern studies remain current, if not made more relevant than ever in the current political moment, when freedom and its universal subject are consistently invoked in aid of endless war.

Writing during World War II, Max Horkheimer and Theodor Adorno were among the intellectuals trying to provide an explanation of the violence they saw around them. The motivating concerns behind their well-known critique of Enlightenment reason remain familiar to our contemporary moment: "Enlightenment, understood in the widest sense as the advance of thought, has always aimed at liberating human beings from fear and installing them as masters. Yet the wholly enlightened earth is radiant with triumphant calamity. Enlightenment's program was the disenchantment of the world. It wanted to dispel myths, to overthrow fantasy with knowledge" (1). These word s could easily serve as an antecedent to the project of subaltern studies, concerned as this project is with the nexus of agency, representation, and political emancipation under conditions of increasing rationalization and instrumentalization of power. One key lesson of subaltern studies is the recognition of the fundamental nonidentity (and I use Adorno's word deliberately) between the apparatus of the state and the citizen-subjects on whose behalf it acts and whom it produces through its actions. The subaltern, moreover, is a figure of pure nonidentity. ${ }^{1}$ For some intellectuals of the Subaltern Studies Collective, this nonidentical nature of the subaltern comes into sharpest relief when one considers that the abstract citizen-subject of rights is a secular abstraction necessary to the disenchantment of the world, of which the modern forms of nation-state are one effect. ${ }^{2}$

Such disenchantment and the attendant rise of the secular state form receive a sustained discussion in Chakrabarty's influential book Provincializing Europe. The figure of the subaltern appears in this work as a subject situated outside the orbit of discourses that claim to represent this figure. The main problematic that Chakrabarty examines is the frustration of the postcolonial historian whose object of study (the subaltern, for example) inhabits an enchanted life-world while modern 
categories of historical narration (inherited from European modernity) are thoroughly disenchanted, secular, and designed to record events as they happen in empty, homogenous time. Subaltern figures and Indian bourgeois subjects are as nonidentical (to return to Adorno's language) to their historical narration in modern regimes of knowledge production as they are to the modern nation-state (Chakrabarty's subaltern figure, as we will see, turns out to be the Bengali middle-class life-world). For Chakrabarty, such figures serve several purposes: they mark the "breach" within our modern categories of historical narration; they make us aware of the "time-knots," or the existence of multiple and simultaneous temporalities, which we inhabit in the everyday; and they index the existence of life-worlds not reducible to capital or other grand narratives of modernity. ${ }^{3}$

Chakrabarty's work is part of a recognizable tradition of left criticism, in which the hegemonic figure (whether cast as the West, imperialism, universal liberalism, or capitalism) is a vehicle for producing a homogenous world-not only through the export and imposition of cultural artifacts but, more insidiously, in its production of epistemological frameworks that claim to speak for the whole globe. The desire of this tradition of criticism tends, in response to the homogenizing imperatives of the powerful, to produce figures of inassimilable difference, whose difference then becomes the ground for resistance to such epistemic, cultural, and political hegemony. ${ }^{4}$ On the one hand, this move resuscitates the subject by producing it as a subversive, resisting, and disruptive agency. On the other hand, it overlooks the fact that hegemonic structures tend as easily to produce difference through the very mechanisms that guarantee equivalence (more on this below). ${ }^{5}$ Laundry lists of unique differences, therefore, are indexes of an interpretive and political desire, a desire that often requires recapitulation to the familiar binarisms of subordination/subversion, homogeneity/heterogeneity, and increasingly, immoral/ moral. ${ }^{6}$ I use the phrase left criticism here because this move is not specific to subaltern studies or postcolonial theory. My critique of projects that seek out difference-as-resistance should not be taken to imply that there is no such thing as difference or resistance. Nor is my primary contention one about essentialism; antiessentialist accounts of difference also continue to cast difference in the role of resistance and disruption. Instead, I take issue with the ease with which, in such critical projects, difference itself comes to secure resistance, disruption, and subversion. To speak of difference means simultaneously to speak of contestation; difference and disruption threaten to sediment and ossify into each other, and it is such 
seemingly natural processes of sedimentation that I hope to unsettle. Once the slippage between difference and disruption is conceded, it is a short step for the subject-in-difference to become the moral subject.

My aim in this analysis is thus twofold: on the one hand, this essay is about reading practices and attempts to begin constructing a reading practice of historical difference through Frankfurt School dialectics and Frantz Fanon's phenomenology of difference. The second aim is to rethink historical difference without the guarantee of subversion, resistance, or disruption that has come to be associated with it in postcolonial thought, in which the subject-in-difference (the subaltern, the racialized subject, etc.) implicitly circulates in a moral economy as the figure of higher moral ground. My reading of Chakrabarty requires detaching his formulations from his interpretive and theoretical context and reanimating them dialectically. Given Chakrabarty's stated hesitance about dialectical reading practices ${ }^{7}$ my reading requires doing violence to these formulations, but I can only hope that such violence is more transformative than destructive. The argument that follows analyzes the problematic ground of historical difference as formulated in Chakrabarty's work, considers how Walter Benjamin's and Theodor Adorno's formulations on mimesis might be useful for such postcolonial considerations, and ends with a reading of Fanon's phenomenology of difference, which suggests a strategy for rethinking mimetic acts and subjects in difference.

\section{History, I and 2}

For Chakrabarty, the primary issue at hand is one of representation: How does one represent experiences-for example, of belief in coeval gods-using the secular master codes of history writing? Chakrabarty turns to Marx for a solution, and outlines what he calls "the two histories of capital.” First, Chakrabarty reminds us of Marx's elaboration: “abstract labor" is what actually mediates the exchange between commodities; not money, but abstract labor forges a social relation between objects, and an object-ive relation between people. ${ }^{8}$ Abstraction not only happens in the practice of exchange, but it happens without one's conscious awareness of it. Moreover, it is the source of the commodity's theological niceties and metaphysical subtleties, and both a precondition and the limit for capital's reproduction.

Through a reading of sections from Theories of Surplus Value and the Grundrisse, Chakrabarty teases out two histories of capital. 
According to the first, capital in its "Becoming" posits its own past, not simply as a calendrical or chronological past, but as "the past that the category [of Capital] retrospectively [and logically] posits" (62-6z). This past is, then, a tautological construction. In Theories of Surplus Value, Marx called this history "capital's antecedent "posited by itself'": in Chakrabarty's words, "This is the universal and necessary history we associate with capital. It forms the backbone of the usual narratives of transition to the capitalist mode of production" (63). Chakrabarty calls this History 1.

To History 1, Chakrabarty opposes History 2, the ground for historical difference, which names a process also described briefly in Theories of Surplus Value, from which he quotes: "Elements of History 2, Marx says, are also 'antecedents' of capital, in that capital 'encounters them as antecedents,' but 'not as antecedents established by itself, not as forms of its own life-process"' (63). So among the antecedents to capital are both relations that aid in its self-reproduction and also others that do not. These antecedents of capital that existed outside of capital's life-processes were, most surprisingly, money and commodity, both of which eventually prove foundational for the conceptualization of capital:

Marx recognizes the possibility that money and commodity, as relations, could have existed in history without necessarily giving rise to capital. Since they did not necessarily look forward to capital, they make up the kind of past that I have called History 2. This example of the heterogeneity Marx reads into the history of money and commodity shows that the relations that do not contribute to the reproduction of the logic of capital can be intimately intertwined with the relations that do. (63)

Capital, according to Marx, must first destroy or subjugate these antecedents to its own logic: "[Capital] originally finds the commodity already in existence, but not as its own product, and likewise finds money circulation, but not as an element in its own reproduction. [. . .] But both of them must first be destroyed as independent forms and subordinated to industrial capital. Violence (the State) is used against interest-bearing capital by means of compulsory reduction of interest rates" (qtd. in Chakrabarty 64). Chakrabarty reads this citation poststructurally: "Marx thus writes into the intimate space of capital an element of deep uncertainty. [. . .] History $2 \mathrm{~s}$ are thus not separate from capital; they inhere in capital and yet interrupt and punctuate the run of capital's own logic" (64). However, Chakrabarty has not quoted Marx fully-the final sentence, if quoted fully, 
should read: "Violence (the State) is used against interest-bearing capital by means of compulsory reduction of interest rates, so that it is no longer able to dictate terms to industrial capital" (Theories 167 ; emphasis added). Earlier Marx writes, "[T]he commercial and interest-bearing forms of capital are older than industrial capital," that is, these, like money and commodity, "in the capitalist mode of production [become] the basicform of the capital relations dominating bourgeois society" (167). Therefore, once capital destroys or subordinates them, they can no longer "dictate terms" to industrial capital. So the "deep uncertainty" written into capital, which for Chakrabarty, in the form of History $2 \mathrm{~s}$, "interrupt[s] and punctuate[s]," appears to do neither, as this "uncertainty," if deep and present at all, seems to be wholly subservient to the logic of the capitalist mode of production. On the subject of these antecedents (commercial and interest-bearing capital, money, and commodity) that capital encounters not as "forms of its own life-process," but that capital destroys or subordinates to itself, Marx continues: "But this [the use of violence through the state] is a method characteristic of the least developed stages of capitalist production. The real way in which industrial capital subjugates interestbearing capital is the creation of a procedure specific to itself-the credit system" (167). We find here both Marx's stagism, which Chakrabarty is keen to ignore in this instance, and an explicit statement that industrial capital eventually does not need an external agent (the state) in order to destroy or subordinate these independent antecedents that it encountered, because its very logic, that is, its very structure "specific to itself," comes to subjugate these antecedents to capital. Which is to say, in later stages, money and commodity are not fundamentally out of joint with themselves, that is, they do not "interrupt and punctuate" the run of capital.

As I mentioned above, Chakrabarty has read Marx's stagism selectively. On the one hand, as Marx himself states in the Grundrisse, the limits to capital are "constantly overcome but just as constantly posited" (410), that is, contradictions can be structural to capital itself. On the other hand, some contradictions would lead to capital's expansion and then create the circumstances of its dissolution. So, schematically, we may say that there are those contradictions that are structural, inherent in the logic of capital, and there are others that become historically sublated into capital and temporally move it toward its dissolution. We notice on closer inspection that for Marx, there is not a strict separation between these two types of negations or "antitheses." For example, while machinery acts to reduce living labor, whose abstraction is the precondition for 
capital's reproduction (so this is a structural contradiction), this reduction also creates the conditions necessary for the abolition of capital and the category of "labor" altogether (here it becomes a historical antithesis). ${ }^{9}$ This later transformation of what I am loosely calling the "structural contradiction" into the "historical contradiction" alludes to Etienne Balibar's central concern in his contribution to Reading Capital: "The only intrinsic result of the contradiction, which is completely immanent to the economic structure, does not tend towards the supersession of the contradiction, but to the perpetuation of its conditions" (Althusser and Balibar 291). ${ }^{10}$ Chakrabary aims to bracket this immanence of the structural contradiction that is at the same time a historical contradiction when he abstracts a radical ambiguity from Marx's claim that "remnants' of 'vanished social formations"” are "'partially still unconquered":

Does "partly still unconquered" refer to something that is "not yet conquered" or something that is in principle "unconquerable"? [. . .] [What] kind of temporal space is signaled by "not yet"? [. . .] The limits to capital, he [Marx] reminds us, are "constantly overcome but just as constantly posited." It is as though the "not yet" is what keeps capital going [. . .] internal to the very being (that is, logic) of capital. [. . .] Difference [. . .] lives in intimate and plural relationships to capital, ranging from opposition to neutrality. $(65-66)^{11}$

As we have seen in the example of technology (machinery) in industrial capitalism, the contradiction simultaneously "keeps capital going" and signals the temporal, historicist reading of "not yet," as that which will partly lead to capital's dissolution. One does not have to choose, then, between the structural reading and the historical one. ${ }^{12}$

That being as it may, it is fruitful to examine the concept of History 2, even if its ground, as outlined by Chakrabarty, is precarious. As we will see, History 2 is the intimate correlative of History 1 , which is to say that it is not the dialectical Other of History 1 and therefore cannot be subsumed into it. (This is the deconstructive move that preserves, without canceling, History 2.) History 2 is constituted by all of those ways of being in the world that the laborer brings to the factory floor that are the supplement to History 1 and the structure of capital's logic. While History 2 in no way impedes the abstraction of labor, it is a sort of grouping of "other kinds of pasts" that "enable the human bearer of labor power to enact other ways of being in the world-other than, that is, being the bearer of labor power" 
(66). Furthermore, this History 2, which interrupts the "totalizing thrusts of History 1," cannot be fully documented: it is composed of pasts "embodied in the person's daily habits, in unselfconscious collective practices, in his or her reflexes about what it means to relate to objects in the world as a human being and together with other human beings in his given environment. Nothing in it is automatically aligned with the logic of capital" (66). Ultimately, History 2 is the basis upon which one may claim historical difference, in that this concept allows one to conceptualize "more affective narratives of human belonging where life forms, although porous to one another, do not seem exchangeable through a third term of equivalence such as abstract labor" (71). Chakrabarty expands the scope of History 2 from commodity and money to include those aspects of one's life-world that remain outside of the logic of capital, even if they are concurrent with History 1 . History 2 is the phenomenological excess that capital cannot subsume; it emerges as a category of thought when History 1 is placed under erasure; and it takes local and differentiated forms.

If History $\mathbf{l}$ is the dominant history that marches on, then History 2 is contained within it, and it marches as well. What, then, is at stake in the concept of History 2 ? The closest thing to an answer provided by Chakrabarty is: "To stay with the heterogeneity of the moment when the historian meets with the peasant is, then, to stay with the difference between these two gestures," the gesture of seeing the colonial peasant as an object of (secular) historical study and as a person who is a contemporary, whose beliefs in spirits could present possibilities for the present. "Taken together," Chakrabarty writes, "the two gestures put us in touch with the plural ways of being that make up our own present" (108; emphasis added). Is History 2 then a heuristic device for the historian, in order that he or she may "stay with" the heterogeneity of the historical object and be "put in touch" with alternate ways of being in the present? It would seem that the back door of poststructuralist reading has led us to the scene of a history written under the imperative that historical categories fully represent the subject in difference. If the aim of historiography is to "stay with" and be "put in touch" with the split subaltern and metropolitan subjects, then what kind of reading (and writing) strategies are adequate to History 2 s? Are "accurate" determinations of such histories-splits, gaps, and differences-possible? The semiotic caesura that Chakrabarty transposes onto the realm of production textualizes materiality, and in this magic trick the material disappears. The enchanted life-world is no more than the space of an 
acknowledged gap in a historiography that aims to represent the present moment accurately.

Which is to say that Chakrabarty's concern with representing the subaltern more accurately requires that we forget the lessons of poststructuralism itself, not least of which is a recognition that the terms of representation-whether linguistic or juridical structures-function through slippage, deferral, and performative gestures whose direction cannot be predicted in advance. Ironically enough, the concern that led Chakrabarty to the formulation of History 2 is poststructuralist in spirit: under what terms of legibility are the Third World and subaltern history narrated? His elaboration of History 2 requires, at a fundamental level, a certain "betrayal" of the poststructuralism he marshals in the service of his analysis because at some point in the analysis this initial question transmutes into a different question: how can we narrate historical difference more accurately? As if this were simply a matter of correcting a distortion. My claim is that History 2 as an analytic is an answer, and a very promising one at that, to a question that is nowhere posed in Chakrabarty's text: what processes of worlding are grounds for historical difference? In order to answer this question, we need to add something to our consideration of historical difference: a theory of mimesis.

Regardless of the precarious philosophical ground of History 2 as formulated by Chakrabarty, such a rich concept may provide a way of conceptualizing historical difference without resorting to cultural relativism. Chakrabarty's account of History 2 highlights and preserves the irreducible particularity of ways of being that escape abstraction. History 2 names precisely such a particularity. The relationship between this particularity and the abstracting mechanism of capital is simultaneously-and paradoxically - one of a bar and an intrusion: History 2 remains outside of the orbit of capital's Becoming and intimately "disrupts" the run of such Becoming, yet it seems to have no effect on the reproduction of capital's conditions of production. To what extent, then, can it be said to be "outside" of capital, since capital has of course constituted History 2 as an outside ("the past that capital logically posits")? The relationship between the particular and the universal, between History 2 and History 1, remains insufficiently addressed.

Within this conundrum of the particular's relation to the universal lies the more fundamental problematic of mimesis, insofar as every articulation of the relationship between the particular and the universal seeks out the precise manner in which each represents the other. Here, 
Benjamin's theory of mimesis is rich with implications for the colonial and postcolonial scene. His formulation is not restricted to conceptions of verisimilitude, but encompasses anthropological, materialist, philosophical, linguistic, epistemological, and aesthetic concerns. The mimetic faculty refers to what he calls nonsensuous or nonrepresentational similarity (unsinnliche Ähnlichkeit); it is the ancient capacity for recognizing correspondences that unconsciously permeate our everyday life. Thinking past theories of mimesis informed by nineteenth-century idealism or even ancient Greek formulations, Benjamin locates the mimetic faculty as the "ur-phenomenon of all artistic activity" (Selected $3: 137,127$ ). Mimesis is associated, variously, with children's play and repetition, the hermeneutics of historical materialism, ancient practices of divination, language, and the twin poles of semblance and play. The myriad of investments congealed in Benjamin's conception of mimesis is precisely the result of the checkered nature of this concept in his work. I would like to tease out the implications of Benjamin's theory of mimesis in relation to his speculations on the concept of history in order to constellate historical difference with a practice of its historical narration.

\section{Mimesis, Semblance, Play}

The concern with mimesis runs through much of Benjamin's oeuvre, from his early essays on language to his later melancholic ruminations on the philosophy of history. In his 1933 fragment "On the Mimetic Faculty," Benjamin writes:

Nature produces similarities; one need only think of mimicry. The highest talent for producing similarities, however, is man's. His gift for seeing similarity is nothing but a rudiment of the once powerful compulsion to become similar and to behave mimetically. There is not a single one of his higher functions in which his mimetic faculty does not play a decisive role.

This faculty has a history, however, in both the phylogenetic and the ontogenetic sense. As regards the latter, play is to a great extent its school. Children's play is everywhere permeated by mimetic modes of behavior, and its realm is by no means limited to what one person can imitate in another. The child plays at being not only a shopkeeper or teacher, but also a windmill and a train. (Selected 3: 720) 
Children mimic objects as well as animals and humans. Fantasy drives the production of nonsensuous correspondences in children's play: "Drawers must become arsenal and zoo, crime museum and crypt. 'To tidy up' would be to demolish an edifice full of prickly chestnuts that are spiky clubs, tin foil that is hoarded silver, bricks that are coffins, cacti that are totem poles, and copper pennies that are shields" (Selected 1:465). Nonsensuous correspondence, the aspect of the mimetic faculty that Benjamin calls the basis of all language, reveals itself in children's play to be a profoundly creative principle by which the given world may be reordered by the child's desire, by which newness itself enters the world. In a footnote to the second version of the work of art essay, Benjamin ponders the intimacy in mimetic practices, between semblance and play:

Dance and language, gestures of body and lips, are the earliest manifestations of mimesis.-The mime presents his subject as a semblance. One could also say that he plays his subject. Thus we encounter the polarity informing mimesis. In mimesis, tightly interfolded like cotyledons, slumber the two aspects of art: semblance and play. [. . .] What is lost in the withering of semblance and the decay of the aura in works of art is matched by a huge gain in the scope for play [Spiel-Raum]. (Selected 3: 127)

The mimetic faculty must be historicized, and, like all perception, it undergoes a transformation with the proliferation of technological reproduction. The newly expanded capacity for play means the production of new possibilities for the channeling of desires and dreams. In fact, Benjamin traces an intimate connection between desire and play: "This second technology is a system in which the mastering of elementary social forces is a precondition for playing [das Spiel] with natural forces. Just as a child who has learned to grasp stretches out its hand for the moon as it would for a ball, so humanity, in its efforts at innervation, sets its sights as much on currently utopian goals as on goals within reach" (Selected 3: 124). This playful reaching out is in fact motivated by a world-historical dream whose object may be impossibly out of reach but yet present on the horizon. Regarding this reaching out to the moon, Miriam Hansen writes, "To a degree, therefore, innervation is necessarily based on miscognition, constituted within the register of the Imaginary (in Lacan's sense): the child will never succeed in grasping the moon. But from this miscognition arise creative and transformative energies (different from the Lacanian scenario), in art as well as in politics" ("Benjamin and Cinema" 324 ). ${ }^{13}$ The 
basis of these creative and transformative energies is the mimetic faculty itself, understood as an embodied form of cognition, or the aesthetic in its root sense. ${ }^{14}$ For Benjamin (as for Lacan), mimesis names the very process of self-fashioning. Unlike the Lacanian model, however, such mimetic self-fashioning is inseparable from worlding, from producing historically specific life-worlds (mimesis-as-worlding). ${ }^{15}$

This happens, of course, in different forms throughout history and throughout the world. Historical difference, then, is not a feature of the Third World and its subjects only. Ernst Bloch, writing around the same time as Benjamin was ruminating on the mimetic faculty, reread Marx's remarks about uneven development as a theory of temporality: "Not all people exist in the same Now. [...] In general, different years resound in the one that has just been recorded and prevails. Moreover, they do not emerge in a hidden way as previously but rather, they contradict the Now in a very particular way, awry, from the rear. The strength of this untimely course has become evident; it promised nothing less than new life, despite its looking to the old" (Bloch 22). Bloch's reading of these "nonsynchronous" ways of being is rigorously dialectical: Nazism marshals such nonsynchronism in its service even as the "new life" promised by these other times existing in the Now could potentially make way for a better order of things. ${ }^{16}$ If history moves within the medium of an empty homogenous time, each present moment is contradicted by nonsynchronicity. Certainly Bloch, like Benjamin and Adorno, is guilty of a Eurocentrism that does not admit of alternate temporalities except within Europe's frame, but the critique of Eurocentrism is a necessary but insufficient ground for rethinking historical difference. In order for a reading practice to do more than point a finger, one must attempt to detach such insights from their discrete contexts, in a Benjaminian spirit, and refunction them for postcolonial thought.

In Benjamin's fragmentary account of the mimetic faculty, it is subject to time's vicissitudes, as the primary figure for articulating the connections between history, mimesis, and dreaming is the child. Humanity, like a child, finds itself adrift and disoriented within the changing configurations of body and image space that new visual technologies make possible, vacillating between an actual experience of the world (and the body) in fragments and a reaching out toward unity and a sense of wholeness. Technology subjects the collective to cognitive training, and Benjamin defines play as "the inexhaustible reservoir of all the experimenting procedures" of modern technology, for which repetition, testing, 
and experimentation are the hallmarks of production. Within the endless testing and experimenting procedures of modern technology, "once is as good as never" (Selected 3: 107). If repetition figures, à la Freud, as a traumatic symptom, ${ }^{17}$ it simultaneously holds out the possibility-as play-of reimagining the course of history. Within the cultural sphere, the figure of the child, marking ontogenesis as well as phylogenesis, encapsulates the predicaments and possibilities faced by humanity confronted by a catastrophic history. In the face of history's repeated failures, mimesis-as a combination of semblance and play-holds out the possibility of trying yet again.

The other side of such revolutionary potential is, of course, endless war and the production of more sophisticated weaponry. Benjamin, like his contemporaries Siegfried Kracauer and Bloch, reads technology dialectically, even if he is prone to greater optimism than his interlocutor, Adorno. In this discussion of mimesis, I would like to emphasize that Benjamin's theories on technology, reproduction, and the historically shifting configurations of sense perception assume a theory of mimesisas-worlding. Mimesis is nowhere foundationally related to capitalism, which is simply one historical means of organizing it. As a beginning of a theory of historical difference, mimesis as an analytic allows for historical insight across both time and geography, but such universalism is not of the order of a classically Marxist teleology, liberal humanist understandings of the subject, imperialist discourses on freedom-the list can go on. Mimesis is the theoretical ground upon which Benjamin's other concerns about history and aesthetics are built, and, as I will show, the concern with the aesthetic in Benjamin can be read as a theory of historical difference.

\section{History and Dialectics}

In Benjamin's work, discussions on mimesis interpenetrate with insights about time and history. The key concept that mediates these two strands of thought-mimesis and worlding, on the one hand, and history and technology, on the other-is sense perception, the root meaning of "aesthetic." What makes Benjamin's thoughts on history and dialectics so elliptical is that he persistently keeps in play two scenes: the scene of the historical materialist and his or her reading practice (or the forms of historical narration themselves) and the referential world, the object that lends unique insight into history. This double scene of interpretation is nothing other than the dialectical method itself. If, as Benjamin writes 
of the mimetic faculty, "seeing similarity" is a residue of the "compulsion" to behave mimetically, then reading practices cannot be detached from the objects they seek to apprehend. If "the questions that humanity brings to nature are in part conditioned by the level of production," not only does nature itself have a history, but the form these questions take are also occasions for reading material realities. Such reluctance to make the scene of reading transparent should appeal to postcolonial theorists, given the concern in postcolonial thought with the histories of institutions and knowledge practices that assume transparency as they seek to manage and regulate the terms of legibility for colonial subjects. The aesthetic artifact (of which, as the reader will note by now, the artwork is simply one example) in Benjamin's work is not a means of showing us how "things really were" in the past, as it would be in a historicist enterprise in the tradition of Wilhelm Dilthey. Rather, to put it in postcolonial terms, the focus on our own scenes of reading asks why this particular difference has drawn our interpretative gaze; what is it about our present moment that makes such a focus imperative? These questions dialectically lead to the second scene and its central questions: what can our object of study reveal about the material realities that produced it and the present realities that have led us to isolate it as an object worthy of study? If theory forgets the referential world that was the source of its inspiration in the first place, it risks becoming no more than a solipsistic enterprise like cultural history, which, according to Benjamin, "may augment the weight of the treasure accumulating on the back of humanity, but does not provide the strength to shake off this burden so as to take control of it" (Selected 3: 268).

A properly dialectical reading process does not deploy "the negation of the negation" in the service of a homogenizing narrative, but it requires that it allow itself to be dialectically transformed by the object, the referential world, rather than adopting a distanced, contemplative attitude toward it. In "Dream Kitsch," Benjamin writes:

What we used to call art begins at a distance of two meters from the body. But now, in kitsch, the world of things advances on the human being; it yields to his uncertain grasp and ultimately fashions its figures in his interior. The new man bears within himself the very quintessence of the old forms, and what evolves in the confrontation with a particular milieu from the second half of the nineteenth century-in the dreams, as well as the 
words and images, of certain artists-is a creature who deserves the name of "furnished man." (Selected 2: 4-5)

Interiority does not exist except through a transformative relationship to the outside world. Historical difference is not a priori and therefore simply a matter of discovery, "objective" positioning in the Marxist sense, but it exists in the interaction between objects and subjects. The form of the object that indexes the specific lifework and epoch has its corollary in the subject whose sense perception has been organized through specific material conditions. So a history that takes account of historical difference would need to attend not only to the products of mimesis but also to the affective and perceptual makeup of the subject who cannot help but be "furnished" by producing it. Benjamin's concern with the historical constitution of perception reminds us that for him the aesthetic is an embodied concept, tied up with the whole constellation of flesh, affect, and sensation, but also imagination, ideation, and thought.

The hermeneutic project for historical materialism is one akin to dream interpretation, read as a functioning of the mimetic faculty, as recognition of nonsensuous correspondences. Benjamin's use of the refuse of history would entail ripping images of the past (because "History decays into images, not into stories" [Arcades N11, 4]) from their context and placing them into constellations with the present. Montage not only sheds light on the objects it juxtaposes but also makes visible its own method. As such, it can be mobilized toward undoing the defining phantasmagoric character of commodities, namely, their dependence on making invisible the traces of their own production. Benjamin gives us an example: "The [Bomber planes] remind us of what Leonardo da Vinci expected of man in flight; that he was to ascend to the skies 'in order to seek snow on the mountaintops and bring it back to the city to spread on the sweltering streets in summer" (Arcades $\mathrm{N}_{18 \mathrm{a}}, 2$ ). A historicist would perhaps place da Vinci's comment in the continuum of his biography or possibly discover through this comment a Renaissance fascination with flying humans, ultimately missing its critical potential for the present moment by enslaving this image in its "context."18 Ripping da Vinci's image out of its context allows us to bring the present into what Benjamin calls "a critical state" (Arcades N7a, 5). Reading becomes a transformative act when discarded images of the past, torn from their discreet historicist contexts, are juxtaposed with other images in order that the historical materialist may scrutinize the context (if you will) of the present moment. This present moment is understood 
not as a telos of past history, but as a possible interruption of it. We see here once again that the historical materialist must be consistently poised for the dialectical movement of destruction and construction, condemnation and redemption, as Benjamin notes in "Central Park": "The course of history, seen in terms of the concept of catastrophe, can actually claim no more attention from thinkers than a child's kaleidoscope, which with every turn of the hand dissolves the established order into a new array. There is profound truth in this image. The concepts of the ruling class have always been the mirrors that enabled an image of 'order' to prevail.-The kaleidoscope must be smashed" (Selected 4: 164). We encounter here the destructive side of dialectics: in the wake of the catastrophe that is history, the first step for the historical materialist is to destroy the kaleidoscope and blast the continuum of homogenous empty time by grasping the images of the past for the present. In juxtaposition to the problematic of historical difference with which Chakrabarty wrestles, Benjamin's vision of the critical project that counters historicism and makes use of the wreckage of history is a universalist vision. ${ }^{19}$ His aim here is to redeem a collective (consciousness): to the universalist, homogenous, empty time, Benjamin opposes a blasting into messianic universal time. ${ }^{20}$ What kind of universality is this? Placed in a context of international relations of production, Benjamin's work raises several intriguing questions, among them: Were the forms of perception organized in the nineteenth and early twentieth centuries universal-like the commodity form itself-both within Europe and also outside of it?

\section{Phenomenology and Difference}

Certainly one must "stretch" Benjamin's categories in order to avoid seeing the outside of Europe simply as a set of particular variations on a "universal" theme whose fundamentals have already been established in Europe. The plea to "stretch" the categories of the Western intellectual tradition to make them useful for postcolonial problematics comes, of course, from Frantz Fanon, who noted that Marxism must be "stretched" to take account of colonial difference. ${ }^{21}$ Fanon's own call for a "new humanity" in the final words of $A$ Dying Colonialism suggests a revised notion of a universal humanity: "The Revolution in depth, the true one, precisely because it changes man and renews society, has reached an advanced stage. This oxygen which creates and shapes a new humanity-this, too, is the Algerian Revolution" (181). I will not detail here the lineaments of 
Fanon's notion of universalism or new humanity, ${ }^{22}$ but I wish to analyze the phenomenology of difference, the play of mimesis, and the historical constitution of the senses that undergird the "true Revolution." Mimesis is central to Fanon's account of the rise of revolutionary consciousness. In A Dying Colonialism, Fanon describes the unveiling of Algerian women who, while "passing” as Europeanized Arab women, work for the Front de Libération Nationale (FLN) and smuggle explosives into the white quarters of colonial Algerian cities. One remarkable passage is worth citing in full:

Observers have compared the action of the Algerian woman to that of certain women resistance fighters or even secret agents of the specialized services. It must be constantly borne in mind that the committed Algerian woman learns both her role as "a woman alone in the street" and her revolutionary mission instinctively. The Algerian woman is not a secret agent. It is without apprenticeship, without briefing, without fuss, that she goes out into the street with three grenades in her handbag or the activity report of an area in her bodice. She does not have the sensation of playing a role she has read about so many times in novels, or seen in motion pictures. There is not that coefficient of play, of imitation, almost always present in this form of action when we are dealing with a Western woman.

What we have here is not the bringing to light of a character known and frequented a thousand times in imagination or in stories. It is an authentic birth in a pure state, without preliminary instruction. There is no character to imitate. On the contrary, there is an intense dramatization, a continuity between the woman and the revolutionary. (5o; emphasis added)

Scholars have rightly critiqued Fanon's gender politics, ${ }^{23}$ and Diana Fuss understandably reads this passage as "Fanon's retrieval of an essentialist discourse of black femininity" in its insistence on instinctual action, "authentic birth," and the emergence of a type of mimicry without a model (151). While the reading I present here departs from Fuss's interpretation, it is inspired by her insight that "identification with the Other [identification of the unveiled Algerian woman with the white European woman] is neither a necessary precondition nor an inevitable outcome of imitation. For Fanon, it is politically imperative to insist upon an instrumental difference between imitation and identification, because it is precisely politics that 
emerges in the dislocated space between them" (153). To read this form of mimesis as a successful instance of identification would mean to render the unveiled Algerian woman the "saved woman" of Western liberalist and colonialist rhetoric-the holy grail of liberal imperialist ideology.

It would seem here that Fanon is rejecting "imitation" and "play" as components of revolutionary mimetic practice, precisely the elements that Benjamin has isolated as the "two aspects" of mimesis. However, such a conclusion is only possible if we read these terms with a dogged literalism, assuming that both Benjamin and Fanon refer to the same thing when they speak of "semblance," "imitation," and "play." Since the term play does not carry the same theoretical weight in Fanon's schema as in Benjamin's, we can assume for the time being that it refers to that which is opposed to the deadly seriousness of FLN revolutionaries. "Imitation," however, is central to Fanon's schema. What the Algerian female revolutionary imitates is not an original found in the mimetic forms of novels or motion pictures; rather, her imitation-of a representation whose original copy is not locatable-itself constitutes an "intense dramatization." As juxtaposed to novels and motion pictures, the intense dramatization is itself a kind of play, a variant of "theatrical improv""theatrical" because it is a test performance and "improv" because its ends are radically open and uncertain, more radically, even, than the most open-ended closures of films and novels. Fanon does not repudiate play altogether, but by means of his concept of imitation, he highlights a particular variety of play. ${ }^{24}$ Like Benjamin, for whom the body of the mime (the ur-figure of mimetic acts) is the primary instrument for the interplay between semblance and play, Fanon insists on the centrality of the body in this scene of intense dramatization. As we will see, he goes further than Benjamin in theorizing the place of the body in the emergence of historically specific forms of mimesis.

For Fanon, "imitation" and "play" are together opposed to instinct; what he means by "imitation" can only be made clear if one analyzes what he means by "instinct." As Fuss writes, political imperative is one key reason for Fanon's insistence that the Algerian woman "learns both her role as 'a woman alone in the street' and her revolutionary mission instinctively." The other reason is that he is cautious about using the term instinct to describe historical difference, that is, the emergence of a uniquely new and local mode of being in the world. In his earlier work, Black Skin, White Masks, Fanon, in what we may read as a radically antiessentialist position, critiques Carl Jung for confusing instinct and habit: 
Instinct, which is inborn (we know how we must view this "innateness"), invariable, specific; habit, which is acquired. On this level one would have only to demonstrate that Jung has confused instinct and habit. In his view, in fact, the collective unconscious is bound up with the cerebral structure, the myths and archetypes are permanent engrams of the race. I hope I have shown that nothing of the sort is the case and that in fact the collective unconscious is cultural, which means acquired. (I88)

The notion of instinct as inborn is already suspect to Fanon; the fiction of inborn impulses has served colonialist politics well. In the accounts he provides of the damaged lives of René Maran and Mayotte Capécia, Fanon shows that while their experiences are inflected by gender, they have both cathected to the archetypes of colonialist typologies in which blackness figures as satanic and whiteness secures the good. Such cathexes are the result of psychic, cultural, and historical conditioning and trauma, not the expressions of inherent instincts. Moreover, such racial wounds do not in themselves guarantee revolutionary consciousness, as the examples of Maran and Capécia make clear. So why, in the case of the revolutionary woman who smuggles weapons and commits terrorist acts, does Fanon resurrect the term instinct to characterize her actions?

The answer lies in Fanon's understanding of the Hegelian dialectic as he articulates it with his own phenomenology of difference (most succinctly put forth in the essay "The Fact of Blackness" in Black Skin, White Masks). His critique of Jean-Paul Sartre allows Fanon to foreground the tension, in part informed by his own clinical experience as a psychoanalyst, between conceptual determination and phenomenological overcoming. The phrase phenomenological overcoming does not appear in Fanon but is best suited to describe both the body that is in his account overcome, threatened, and inundated with racial typologies and the new body that sublates the meanings and traumas inflicted upon it. The "moment" (to use Hegelian language) between these two bodies is one of a radical transformation and the proper place of what Fanon would call "instinct" in A Dying Colonialism. In the earlier work, Black Skin, White Masks, Fanon sketches the dialectical significance of such a moment in his critique of Sartre's Black Orpheus. According to Fanon, Sartre reads negritude as a moment in the unfolding of a historical dialectic: negritude is the "minor term" of negativity that itself will be sublated in the formation of a new reality. Fanon responds to this reading: 
When I read that page, I felt that I had been robbed of my last chance. I said to my friends, "The generation of the younger black poets has just suffered a blow that can never be forgiven." Help had been sought from a friend of the colored peoples, and that friend had found no better response than to point out the relativity of what they were doing. For once, that born Hegelian had forgotten that consciousness has to lose itself in the night of absolute, the only condition to attain to consciousness of self. In opposition to rationalism, he summoned up the negative side, but he forgot that this negativity draws its worth from an almost substantive absoluteness. A consciousness committed to experience is ignorant, has to be ignorant, of the essences and the determinations of its being. (133-34)

Fanon's criticism here of the negation of the negation, which would position negritude as a moment of historical emergence in the service of a telos, is not a criticism of the dialectic itself, but of Sartre's limiting deployment of it. ${ }^{25}$ In spite of his own ambivalences about negritude, it is of paramount political and philosophical importance for Fanon that black consciousness "lose itself in the night of the absolute," and this is what negritude signifies. To experience the night of the absolute means to forget one's own determination, as in a Nietzschean moment in which forgetting is central to the forging of truth. Nietzsche describes the relationships between forgetting, truth, and the historically significant action thus: "The historical sense makes its servants passive and retrospective; and almost the only time the sufferer from the fever of history becomes active is when this sense is in abeyance through momentary forgetfulness" (102). For Fanon, the truth that emerges from black consciousness is possible only via a phenomenological reassembly of the self, a process that is only possible with revolutionary action itself. Such action can take aesthetic forms (such as those created by the writers and philosophers of negritude), as well as "properly" political forms (the F LN, for example), but the precondition of such revolutionary impulses is a foundational forgetting. For Fanon, the emergence of the black revolutionary consciousness does not happen ex nihilo, since the trauma that is colonialism provides its basic components. Bodily perception necessarily remains central to this self's constitution since it was the access point for the black subject's original trauma, reduced as he or she is to sheer skin, to sheer surface. ${ }^{26}$ Importantly for Fanon, there is no guarantee that the trauma of colonialism 
will lead to the conditions of a revolutionary consciousness, and even after decolonization, the subversive energies of revolutionary acts can be easily appropriated by the nationalist bourgeoisie. ${ }^{27}$ But the "night of the absolute," in which conceptual determination is forgotten for the sake of an instinctual mimetic practice (aesthetic and political), is the crucible for a new humanity.

By pointing out the tension between the dominative aspect of conceptual thinking (whose essence can be paraphrased as "to determine something is to kill it") and the phenomenological bodily experience of subjects under colonialism, Fanon is not carving out a prediscursive space of revolutionary energies, since the "night of the absolute" happens in history, and its precipitate-revolutionary consciousness-is formed out of given historical and cultural schemas. Fanon's argument here correlates with Benjamin's and Adorno's reflections on mimesis, which locate it as a potentially revolutionary faculty associated with magical rites, ritual, and bodily experiences. ${ }^{28}$ For Adorno, mimesis names a nondominating form of apprehending the world, and like the repressed, it returns in modernity in destructive forms. Nevertheless, Adorno explains, "[M]imetic behavior does not imitate something but assimilates itself to that something" (162). ${ }^{29}$ So even if the women of the FLN appear to imitate European women, they are demonstrating their assimilation not to European comportments but to the forms of being found in the "night of the absolute." Similarity is not the same as equivalence, and assimilation is not always capitulation. Like all historical dialectics, this drama of mimesis has its necessary destructive side, but the nature of its destruction is not synonymous with domination; rather, it is a violent rejection of the present order of things. The violence entailed in the self's phenomenological overcoming need not necessarily lead to new forms of domination and control. And yet the revolutionary act remains a fragile opening, potentially subject to appropriation by newly dominating structures of the postcolonial state. So revolutionary action is a kind of mimetic experimentation, "playful” in Benjamin's sense, ${ }^{30}$ and it is bound to succeed or fail with no guarantees. Fanon's use of the word instinct turns out to refer not to a historically unvarying, deep-rooted essence, but to a historically situated phenomenological experience.

\section{Reading Historical Difference}

I began this essay by considering the problem of self-conscious reading practices that attend to the gap between their own concepts and 
the objects at hand. The redefinition of historical difference I would like to suggest is, in the spirit of the thinkers examined here, a reorientation of reading practices. Each of the thinkers is concerned, in different ways, with the coercive relationship of the universal to the particular.

This relationship between the particular and the universal, as a political-philosophical problem, cuts across postcolonial thought in a diverse array of problematics: the production of the subject of rights, the hegemony of the nation-state form, the subaltern subject, the writing back to empire, and so on. In Marx's account of labor, this relationship is a hierarchical one: abstraction is the horizon upon which particularity disappears. Real labor becomes meaningful as such only when the work of abstraction has converted it to abstract labor. Particularity, in other words, only becomes legible at the moment of its disappearance into the general, or universal. For Chakrabarty, the hope for postcolonial historiography rests in arresting this irreducible particularity as the brute, inassimilable character of his subject/object (the subaltern, for example) that creates a "breach in history's systems of representations." In Marx's Hegelian understanding, the particular seems destined for incorporation into the general: Real Labor becomes Abstract Labor; the particular class (the proletariat) becomes a placeholder for the universal interests of humanity. The object is fully congruent with its concept, and when it is not, then history is a dialectical process of it becoming so.

Adorno and Benjamin sought a way out of such idealist assumptions, the source of philosophy's confrontation with false antinomiesamong others, the tyranny of the concept, on the one hand, and the opacity of the Kantian thing-in-itself, on the other. Their solution-the constellation-represented a methodology as well as a thought figure. In the Trauerspiel study, Benjamin writes that "ideas are to phenomena as constellations are to stars" implying a radical relationship of dependence between the universal and the particular (Origin 34; trans. mod.). His concept of a constellation preserves the sense of a whole without tethering that wholeness to a determining and absolute principle, as in Hegel. This aspect of Benjamin's thought, developed in collaboration with Adorno, is central to the contribution these thinkers have to make to postcolonial problematics. The relationship between the particular and the general, the concrete and the abstract, is foundational to Chakrabarty's contentions in particular and postcolonial thought in general.

As a representation of truth, which for Benjamin and Adorno is historically transient and materially mediated, the constellation seeks 
to present the relationship between the particular and the general as a relationship. A rigorously materialist methodology, the constellation foregrounds the referential world that was the source of philosophy's inspiration in the first place. The material phenomenon, as the object, is broken into its elements and, as Susan Buck-Morss explains, "[These] particulars, although conceptually mediated, reemerge in the idea; or more accurately, they become the ideas in the conceptual arrangement of their elements. The role of the subject, to draw connections between phenomenal elements, was not unlike that of the astrologer, who perceived figures in the heavens" (Origin 92). ${ }^{31}$ The mimetic faculty underpins both the recognition of constellations and the recognition of their truth. Mimesis, in the form of the constellation, allows for a noncoercive coexistence of nonidentical particulars. The elements in constellations do not stand in relations of hierarchy among themselves, but foreground the interplay between totality and the particular as a productive tension through which truth-in all of its historical transience-is born. The totality does not subsume any of its elements, and since in it truth results from the conceptual arrangement of the elements in all of their particularity, the relationship of the particular to the general is nonidentical. The constellation stages nonidentity as method.

In an epigraph to Convolute $\mathrm{N}$, "On the Theory of Knowledge, Theory of Progress,” widely acknowledged as Benjamin's statement on method, he cites Marx: "Our election cry must be: Reform of Consciousness not through dogmas, but through the analysis of mystical consciousness that is unclear to itself, whether it appears in a religious or a political form. Then people will see that the world has long possessed the dream of a thing-and that it only needs to possess the consciousness of this thing in order to really possess it" (Arcades N5a, 1). The "not-yet" posited by Benjamin's elaboration of this Marxist problematic, the disjuncture between the "dream of a thing" and the "consciousness of this thing" is not of the order of the structural contradictions in the base that would lead to the abolition of capital. Neither is it the "not-yet" that refers, as Chakrabarty puts it in his revisionist deconstructivist reading of structural contradictions, to "a process of deferral internal to the very being (that is, logic) of capital. [...] Difference lives in intimate and plural relationships to capital, ranging from opposition to neutrality" (66). Rather, this "not-yet" is akin to the nunc stans of Bloch, in which the present is figured as impeded yet simultaneously pregnant with possibility. The schism between the particular historical reality and the utopic promise of the commodity is simply the 
space between two elements in a constellation; if the commodity promises fulfillment, it simultaneously creates desire for a different order of things, a desire generated by the treadmill of history's past and present failures. ${ }^{32}$ For Fanon, such desire is the basis for the first revolutionary action.

Historical difference, then, may be redefined as the following: the precise organization of form and perception under specific historical conditions, the particular mimetic strategies of a historical collective, and also the phenomenological comportment toward futurity that is at the same time a historically specific apprehension of the past. In other words, History 2 s have their own temporal and representational dialectics. Rethinking History 2 on this interpretive terrain means bringing it back into a dialectical movement rather than attaching it as a constitutive core of capital, a move, in my mind, that only allows us to observe and describe more closely the status quo, giving succor to an additive analysis that can lapse into a defanged form of empiricism. ${ }^{33}$ The representation and recognition of historical difference itself cannot provide a guarantee that the (Derridean) supplement we have located will fulfill our expectations of disruption or that the phenomenon will become a trace or a supplement in this sense simply because we name it so. ${ }^{34}$

If we read History 2 not as the process within capital that endlessly defers the Becoming of the commodity, but rather as the result of the dialectic that takes place in the mimetic realm, the dialectic that brings the past into legibility through mimetic forms, then how do we conceive of historical difference? In the former schema, historical (this includes cultural, racial, and sexual) difference acquires the status of a Derridean supplement. In the latter, perhaps we can reorient the deconstructive function of the supplement toward the realm of the material. The power of History 2, then, lies not in the mere reflection of the practices of alternate temporalities, of the enchanted life-world, but in the historically specific forms of questioning (mimetic reading) about why the world got made (mimesis-as-worlding) in the way it did (mimetic forms).

In such a reformulation, History 2 does not slip into a romanticism that defines it as consistently disruptive of History 1; one risks fetishizing difference if the historian has decided in advance to reveal it as the particular-that-disrupts. This becomes all the more problematic when such difference is intended to guarantee the political progressiveness of our intellectual projects or the moral rectitude of our objects and subjects in difference. ${ }^{35}$ Along with considering subaltern difference, we must also consider the difference of contemporary postcolonial and "First World" 
politicians and supporters of the nation-state, who also "believe in" supernatural beings. Insofar as theological language becomes central to their conservative platforms, we cannot ignore the conservative (or potentially progressive) role of, for example, gods in the nation-state. By rethinking historical difference dialectically, we can not only accommodate indigenous difference but also arm a critical project against indigenous versions of domination. Enumerating differences, gaps, caesurae, and so on, cannot in itself be the object(ive) of history writing if capital produces and relies upon difference because of its logic of equivalence. This means not that difference is tethered to the universal, but that it cannot exist except in a negative dialectical relation to it.

Insofar as History 2 illuminates historical difference-alternative ways of being in the world that have been written over by the narratives of modernity, citizenship, and the nation-state-Chakrabarty's insistence that we turn to the "dreamed-up pasts and futures whose collectivities are defined neither by the rituals of citizenship nor by the 'nightmare' of tradition that 'modernity' creates" needs to be taken seriously. The central question that Fanon had isolated as the constant preoccupation of the colonized remains relevant for postcoloniality: "Who am I, in reality?" (Wretched 182). Adorno's and Benjamin's oeuvre lays out a fragmented theory of perception and mimesis in which perception is not merely a way of seeing but simultaneously a way of becoming. For colonial/postcolonial subjects, the answer to Fanon's question can be sought partially in the mimetic forms of their modern life-world and in its genealogies.

Thanks to Susan Buck-Morss, Rey Chow, Iftikhar Dadi, Biodun Jeyifo, Natalie Melas, and Geoff Waite for their close readings of this essay. I am also indebted to David Sartorius and Ellen Rooney for their helpful feedback and suggestions.

Zahid r. chaudhary is Assistant Professor of English at Princeton University and the author of Afterimage of Empire: Photography in Nineteenth-Century India (University of Minnesota Press, 2012). This essay is drawn from his current book project, "Mimetic Acts: The Play of Difference in Late Modernity."

Notes 1 The subaltern is not, therefore, a member of a class as such (think Marx's Eighteenth Brumaire); as a class, it is constative rather than performative. In a recent essay, Spivak calls subalternity "a position without identity," which is to say, "[S]ubalternity is where social lines of mobility, being elsewhere, do not permit the formation of a recognisable basis of action" ("Scattered" 476). Spivak's use of the word "identity" is very different from Adorno's use. Spivak refers to the production of political subjects who 
may metonymically represent themselves in the political order; Adorno refers to the process of capture whereby the concept exhausts its referent.

On the universal subject of rights, see (among others) Benhabib; and Butler, Laclau, and Žižek.

Strictly speaking, Chakrabarty's project in Provincializing Europe is not a project about subalternity. The subaltern figure is a point of departure for analyzing forms of affiliation and ways of being in the world that exceed modern grids of legibility (the national subject, nation-state form, etc.). For a critique of Chakrabarty's use of the term "subaltern," and of Provincializing Europe as a whole, see Kaiwar, "Silences" and "Towards."

Aamir Mufti discusses a similar impulse, what he calls the "aura of authenticity," in postcolonial criticism. See Mufti. Rey Chow elaborates on a tendency in certain postcolonial work, "which may be paraphrased as follows: deconstruct the danger and pitfalls of a certain term in its conventional usage; rescue that term for its inherent 'heterogeneity' and 'difference'; affirm this 'heterogeneity' and 'difference' when it is used by certain groups of people" (Primitive 191).

5 Responding to Michael Hardt and Antonio Negri's argument that the local is often a production of the global, Chakrabarty writes in a new introduction to the latest edition of Provincializing Europe: "Difference is not always a trick of capital. My sense of loss that ensues from my globalization does not always make a consumer of me. Often the loss in question relates to cultural practices that, so to speak, will no longer 'sell.' Not every aspect of our sense of the local can be commodified (I wish it could)" (xviii). Chakrabarty is, of course, correct in that all affect is not grist for capital's mill. But making a consumer of someone is not the only trick of capital. Nevertheless, taking Chakrabarty on his own terms, the qualification missing from this statement is, of course, that affects can and do become commodified now and again, even if their use by capital is not simply restricted to commodification. For a critique of Chakrabarty's treatment of identity, see Ismail.

6 Saba Mahmood has written about the ways in which such binarisms in Western feminism reproduce the logics of liberalism itself.

7 In Chakrabarty's account, dialectical hermeneutics only appears as an example of the homogenizing impulse of all Eurocentric reading practices. To cite one example: "These voices [of difference] [...] remind us of the deep ambivalences that marked the trajectory of the modern private and bourgeois individuality in colonial India. Yet historians manage, by maneuvers of the old 'dialectical' card trick called 'negation of negation,' to deny a subject position to this voice of ambivalence" (38).

8 As Marx writes, “[B]y equating their different products to each other in exchange as values, they equate their different kinds of labour as human labour. They do this without being aware of it" (Capital 167 ).

9 “[C]apital [...]-quite unintentionally-reduces human labor, expenditure of energy, to a minimum. This will redound to the benefit of emancipated labour, and is the condition of its emancipation" (Marx, Grundrisse 701). 
10 The full quotation reads:

The only intrinsic result of the contradiction, which is completely immanent to the economic structure, does not tend towards the supersession of the contradiction, but to the perpetuation of its conditions. The only result is the cycle of the capitalist mode of production. [. . .] The "limit" towards which the movement of the mode of production tends [. . is] not therefore a question of a ladder, of a threshold to be attained. If the tendency cannot pass these limits, it is because they are inside it, and as such never reached: in its movement it carries them with it, they coincide with the causes which make it a "mere" tendency, i.e., they are simultaneous with its actual conditions of possibility. (Althusser and Balibar 29I)

Chakrabarty makes it explicit that by differentiating History 1 and 2 he is not referring to "uneven development," a concept that has a long and varied history in Marxist theory. In his own words, this concept presumes "at least an underlying structural unity (if not an expressive totality) to historical process and time that makes it possible to identify certain elements in the present as 'anachronistic" (12). Such a concept, in Chakrabarty's view, is of a piece with the kind of historicism from which he wishes to distance himself. See also his "Epilogue: Reason and the Critique of Historicism" in Provincializing Europe (237-56).

12 Incidentally, in Chakrabarty's account it is unclear whether History 2 names a structural or a historical process. In Marx, such ambiguity is the source of capital's logic of reproduction. Yet Chakrabarty prefaces his deconstructive reading of History 2 as a "process of deferral internal to the very being (that is, logic) of capital" by stating: "Marx himself warns us against understandings of capital that emphasize the historical at the expense of the structural or the philosophical" (65). But as we have seen, history and structure are not mutually exclusive in Marx's account. By emphasizing the "structural" aspects of History 2 but nevertheless naming it "History," Chakrabarty's conception remains densely textured and more complex than his own account of it would allow.

13 For a sustained discussion of how Benjamin's conception of innervation is grounded in the mimetic faculty, and the differences between the psychoanalytic and Benjaminian meanings of the term, see Hansen, "Benjamin and Cinema."

14. In a fragment from 1936 - the same year in which he wrote the artwork essay-Benjamin writes, "Perhaps Stone Age man produced such incomparable drawings of the elk only because the hand guiding the implement still remembered the bow with which it had felled the beast" (Selected 3: 258). All forms of mimesis assume a bodily foundation for the mimetic capacity, and the ancient form of mimesis is associated here with what Benjamin calls Erfahrung, or "long experience" in the 1940 essay, "On Some Motifs in Baudelaire."

15 At the same time, as Michael Taussig's work demonstrates, mimesis is inseparable from alterity. To mime the other means to project oneself outward to the other and be in the other's place. See Taussig, Mimesis and Nervous. For a critique of Taussig's account, see Jay, "Unsympathetic." For the ensuing exchange between Martin Jay, Michael Taussig, and Paul Stoller, see Jay, "Martin"; Stoller; and Taussig, 
"Michael." See Huggan for a critique of Taussig's conflation of mimicry with mimesis.

Chakrabarty includes Bloch in his condemnation of historicism (12) and notions of uneven development but misses the import of Bloch's dialectical reading of the nonsynchronous that reads the contemporaneous as coeval with the present, a trace of the past, yet also a possibility for the future. Bloch's reading, in fact, breaks with rather than supports the sort of historicism that Chakrabarty himself critiques.

17 Repetition, the sectioning of time, the search for heightened sensation, and the fragmented nature of experience can lead, in the modern age, to a fatal spiral of aesthetics and anaesthetics. See Buck-Morss, "Aesthetics."

Such contextualization, incidentally, is another important meaning of historicism in the German intellectual tradition in general, and in Benjamin and Dilthey in particular. See Dilthey. I am grateful to Susan Buck-Morss for pointing this out.

Chakrabarty also takes historicism to task. To the modern tradition of historicism-especially as it found articulation in the "colonial theatre," where "the theme of 'freedom,' as defined by modern political philosophy, was constantly invoked in aid of the ideas of 'civilization,' 'progress,' and latterly, 'development" - he suggests the following response: "The task, as I see it, will be to wrestle with ideas that legitimize the modern state and its attendant institutions, in order to return to political philosophy-in the same way as suspect coins are returned to their owners in an Indian bazaar-its categories whose global currency can no longer be taken for granted" (45). The historian must critique historicism but also find strategies for conceptualizing historical difference without abandoning a "commitment to theory" (46). At bottom, it is the universalism of the hegemonic narratives of citizenship and the modern state with which Chakrabarty finds fault.

Benjamin's messianism is a source of disappointment for some commentators. However, Hansen makes an intriguing argument that it is precisely Benjamin's messianism that prevents him from assuming a previously unalienated state of being. See Hansen, "Room-for-Play." Jewish mysticism here is akin to a methodology, much like psychoanalysis. For a reading of Benjamin's messianism as methodology, see Buck-Morss, Dialectics 229-52.

21 "In the colonies the economic substructure is also the superstructure. The cause is the consequence; you are rich because you are white, you are white because you are rich. This is why Marxist analysis should always be slightly stretched every time we have to do with the colonial problem" (Fanon, Wretched 40).

22 Some illuminating discussions of Fanon's universalism include Malik; Mazrui; and Melas.

23 See "Interior Colonies" in Fuss (141-65); Bergner; Chow, "Politics"; Doane; Goldie; Khanna; and Sharpley-Whiting.

24. I am indebted to Diana Fuss for this insight.

25 For a fuller account of Fanon's deployment of dialectical thinking, see Sekyi-Otu.

26 In an astute analysis of Fanon's phenomenology, read through Maurice Merleau-Ponty, Gayle 
Salamon makes the case that for Fanon, the phenomenological difference that race makes is to deprive the subject of a place of retreat within itself.

27 See "Pitfalls of National Consciousness" in Fanon, Wretched (14,8-205).

Of course, in The Wretched of the Earth, Fanon describes the beginnings of nationalist consciousness as a retrieval and invention of local tradition: in the form of rites, rituals, dances, poetry.

29 Adorno uses the word sich anschmiegen (nestle oneself against) rather than Nachahmung (imitation) in this discussion of mimesis. For the valences of these different terms in German, see Jay, "Mimesis and Mimetology." For a discussion of the relevance of anschmiegen for historically different aesthetic practices, see my Afterimage of Empire (125-31). The present quotation about mimetic behavior assimilating itself to something is from Lenhardt's earlier (1984) translation, though neither the earlier nor the latest translation is consistent with respect to the verb sich anschmiegen, locating it when it is not there in the original, or rendering it unrecognizable when it is there. Adorno's original text corresponding to Lenhardt's translation reads: "Ahmt das mimetische Verhaltn nicht etwas nach, sondern macht sich selbst gleich, so nehmen die Kunstwerke es auf sich, eben das zu vollziehen" (Ästhetische 169). However, when Adorno actively uses the verb sich anschmiegen, he writes: "In den Kunstwerken ist der Geist zu ihrem Konstruktionsprinzip geworden, aber genügt seinem Telos nur dort, wo er aus dem zu Konstruierenden, den mimetischen Impulsen, aufsteigt, ihnen sich anschmiegt, anstatt daß er ihnen souverän zudiktiert würde" (Ästhetische 180). The newer, now standard translation by Hullot-Kentor (1997) renders this as, "In artworks spirit has become their principle of construction, although it fulfills its telos only when it emerges from what is to be constructed, from the mimetic impulses, by shaping itself to them rather than allowing itself to be imposed on them by sovereign rule" (118). Adorno develops this alternate notion of mimesis particularly in the section titled "Semblance and Expression" (Hullot Kentor, trans., 100-117) in Aesthetic Theory, but also in Dialectic of Enlightenment (with Horkheimer). The secondary literature on Adorno's (and Horkheimer's) conception of mimesis is vast, but with respect to Adorno's use of the word anschmiegen and its related neologism, anbilden ("to image onto"), Michael Cahn's and Martin Jay's discussions of these terms are indispensable.

"Play" in this account does not refer to the poststructuralist category of "free play," with its emphasis on the textual dimensions of play in the field of meaning. Instead, it refers to a materialist and dialectical aspect of mimesis in which engagement with objective realities transforms those realities through performance, gambling (risk-taking), and games. These three strands of play encompass some of the multiple meanings of the German word Spiel. For more on Benjamin's notion of play, see Hansen, "Room-for-Play." An alternate and non-poststructuralist genealogy of play can be constructed through the works of Friedrich Schiller, Johan Huizinga, Roger Caillois, Karl Krauss, Adolf Loos, and of course, Theodor Adorno and Frantz Fanon. 
31 For a detailed account of the constellation in Benjamin's and Adorno's work, see Buck-Morss, Origin 82-110.

32 For an elaboration of this aspect of Benjamin's work, see BuckMorss, Origin 110-58.

33 Empiricism is most insightful when its objects transform theoretical apparatuses rather than becoming a means for filling out, in an additive manner, a prefigured theoretical design. As a thought figure, the constellation reenergizes empiricism by holding out a critical space in thought for the concrete particular that is not subsumed by the general, or simply marshaled in its service.
34. The performative gestures of interpretation meet their limit in the intractability of actually existing objects and facts, whose presence, though mediated, must energize and transform theory if the latter is to have any material grounding.

35 To take one example, in 1998 in India, Prime Minister Vajpayee encouraged people to place ashes from the nuclear testing done that year as offerings at temples. In this case History 2 is not progressive or disruptive, but participates in the phantasmagoria of modernization and citizenship. For a more detailed account of this event, see Aravamudan.
Works Cited

Adorno, Theodor W. Aesthetic Theory. Ed. Gretel Adorno and Rolf Tiedemann. Trans. C. Lenhardt. London: Routledge, 1984.

Aesthetic Theory. Ed. Gretel Adorno and Rolf Tiedemann. Trans. Robert Hullot-Kentor. Minneapolis: U of Minnesota P, 1997. Ästhetische Theorie. Frankfurt: Suhrkamp, 1973 .

Alessandrini, Anthony C., ed. Frantz Fanon: Critical Perspectives. New York: Routledge, 1999. Althusser, Louis, and Etienne Balibar. Reading Capital. Trans. Ben Brewster. London: NLB, 1970.

Aravamudan, Srinivas. Guru English: South Asian Religion in a Cosmopolitan Language. Princeton: Princeton U P, 2005.

Benhabib, Seyla. The Claims of Culture: Equality and Diversity in the Global Era. Princeton: Princeton UP, 2002.

Benjamin, Walter. The Arcades Project. Ed. and trans. Rolf Tiedemann. Cambridge, ma: Harvard UP, 1999.

The Origin of German Tragic Drama [Ursprung des deutschen Trauerspiels]. London: Verso, 1998.

Selected Writings, Vol. 1: I9I3-I926. Ed. Marcus Bullock and Michael Jennings. Cambridge, MA: Harvard u P, 1999.

Selected Writings, Vol. 2: 1927-1934. Ed. Michael Jennings et al. Cambridge, MA: Harvard uP, 1999 . Belknap, 2002.

Selected Writings, Vol 3: 1935-1938. Ed. Michael Jennings. Cambridge, ma: 
Selected Writings, Vol. 4: 1938-1940. Ed. Howard Eiland and Michael Jennings. Cambridge, м A: Belknap, 2003.

Bergner, Gwen. "Who Is That Masked Woman? Or, The Role of Gender in Fanon's Black Skin, White Masks.” PMLA 110.1 (1995): 75-88.

Bloch, Ernst. "Nonsynchronism and the Obligation to Its Dialectics." Trans. Mark Ritter. New German Critique 11 (Spring 1977): 22-38.

Buck-Morss, Susan. "Aesthetics and Anaesthetics: Walter Benjamin's Artwork Essay Reconsidered." October 62 (Autumn 1992): 3-4,1.

The Dialectics of Seeing: Walter Benjamin and the Arcades Project. Cambridge, MA: MIT P, 1991.

Origin of Negative Dialectics. New York: Free Press, 1977.

Butler, Judith, Ernesto Laclau, and Slavoj Žižek. Contingency, Hegemony, Universality: Contemporary Dialogues on the Left. London: Verso, 2000.

Cahn, Michael. "Subversive Mimesis." Mimesis in Contemporary Theory: The Literary and the Philosophical Debate. Ed. Mihai Spariosu. Amsterdam: John Benjamins, 1984. 27-55.

Chakrabarty, Dipesh. Provincializing Europe: Postcolonial Thought and Historical Difference. Princeton: Princeton u, 2007.

Chaudhary, Zahid R. Afterimage of Empire: Photography in Nineteenth-Century India. Minneapolis: U of Minnesota P, 2012.

Chow, Rey. "The Politics of Admittance: Female Sexual Agency, Miscegenation, and the Formation of Community in Frantz Fanon.” Alessandrini 209-4,8.

Primitive Passions: Visuality, Sexuality, Ethnography, and Contemporary Chinese Cinema. New York: Columbia up, 1995.

Dilthey, Wilhelm. Meaning in History. Crows Nest: Allen and Unwin, 1961.

Doane, Mary Ann. "Dark Continents: Epistemologies of Racial and Sexual Difference." Femmes Fatales: Feminism, Film Theory, Psychoanalysis. New York: Routledge, 1991. 209-48.

Fanon, Frantz. Black Skin, White Masks. New York: Grove, 1967.

A Dying Colonialism. New York: Grove, 1994.

The Wretched of the Earth. New York: Grove, 2005.

Fuss, Diana. Identification Papers: Readings on Psychoanalysis, Sexuality, and Culture. New York: Routledge, 1995 .

Goldie, Terry. "Saint Fanon and Homosexual Territory.” Alessandrini 77-88.

Hansen, Miriam Bratu. "Benjamin and Cinema: Not a One-Way Street." Critical Inquiry 25.2 (Winter 1999): 3o6-43.

"Room-for-Play: Benjamin's Gamble with Cinema." October 109 (Summer 2004): 3-45. 
Horkheimer, Max, and Theodor W. Adorno. Dialectic of Enlightenment. Palo Alto: Stanford UP, 2007.

Huggan, Graham. "(Post)Colonialism, Anthropology, and the Magic of Mimesis." Cultural Critique 38 (Winter 1998): 91-106.

Ismail, Qadri. "(Not) at Home in (Hindu) India: Shahid Amin, Dipesh Chakrabarty, and the Critique of History." Cultural Critique 68 (2008): 210-47.

Jay, Martin. "Martin Jay Replies to Michael Taussig and Paul Stoller." Visual Anthropology Review 10.1 (1994): 163-64.

. "Mimesis and Mimetology: Adorno and Lacoue-Labarthe." The Semblance of Subjectivity: Essays in Adorno's Aesthetic Theory. Ed. Tom Huhn and Lambert Zuidervaat. Cambridge, MA: мIт P, 1999. 29-54.

“Unsympathetic Magic.” Visual Anthropology Review 9.2 (1993): 79-82.

Kaiwar, Vasant. "Silences in Postcolonial Thought." Economic and Political Weekly 40.34 (20 Aug. 2005): 3732-38.

"Towards Orientalism and Nativism: The Impasses of Subaltern Studies." Historical Materialism 12.2 (2004): 189-247.

Khanna, Ranjana. Dark Continents: Psychoanalysis and Colonialism. Durham: Duke uP, 2003 .

Mahmood, Saba. Politics of Piety: The Islamic Revival and the Feminist Subject. Princeton: Princeton UP, 2005.

Malik, Kenan. "Universalism and Difference in Discourses of Race." Review of International Studies 26.05 (2000): 155-77.

Marx, Karl. Capital: A Critique of Political Economy. New York: Penguin, 1990.

Grundrisse: Foundations of the Critique of Political Economy. Ed. and trans. Martin Nicolaus. New York: Penguin, 1993.

Theories of Surplus Value. Amherst: Prometheus, 2000.

Mazrui, Alamin. "Relativism, Universalism, and the Language of African Literature." Research in African Literatures 23.1 (Spring 1992): 65-72.

Melas, Natalie. "Humanity/Humanities: Decolonization and the Poetics of Relation." Topoi 18.1 (1999): 13-28.

Mufti, Aamir R. "The Aura of Authenticity." Social Text 18.3 (2000): 87-103.

Nietzsche, Friedrich Wilhelm. Untimely Meditations. Ed. Daniel Breazeale. Trans. R. J. Hollingdale. Cambridge: Cambridge up, 1997.

Salamon, Gayle. “The Place Where Life Hides Away': Merleau-Ponty, Fanon, and the Location of Bodily Being." differences: A Journal of Feminist Cultural Studies 17.2 (2006): 96-112.

Scott, David. Conscripts of Modernity. Durham: Duke up, 2004.

Sekyi-Otu, Ato. Fanon's Dialectic of Experience. Cambridge, M A: Harvard u P, 1997. 
Sharpley-Whiting, T. Denean. "Fanon and Capécia." Alessandrini 59-76.

Spivak, Gayatri Chakravorty. "Can the Subaltern Speak?” Marxism and the Interpretation of Culture. Ed. Cary Nelson and Lawrence Grossberg. Bloomington: U of Illinois P, 1988. 271-313.

"Scattered Speculations on the Subaltern and the Popular." Postcolonial Studies 8.4 (November 2005): 475-86.

Stoller, Paul. "Double Takes: Paul Stoller on Jay on Taussig." Visual Anthropology Review 10.1 (1994): 155-62.

Taussig, Michael T. “Michael Taussig Replies to Martin Jay.” Visual Anthropology Review 10.1 (1994): 154 .

Mimesis and Alterity: A Particular History of the Senses. New York: Routledge, 1993.

The Nervous System. New York: Routledge, 1992. 